\title{
A Study of Underburning in Stands of $P$. yunnanensis and $P$. Kesiya var. langbianensis
}

\author{
WU DEYOU, YANG FUCHENG, YI SHAOLIANG, YANG CONGXIN and \\ WANG PEI \\ Southwestern Forestry College \\ Kunming, P.R. China
}

ABSTRACT The stands of $P$. yunnanensis and $P$. kesiya Var. langbianesis less than 8-11 years cannot be underburned and those of 8-11 years ust be pretreated once by thinning before underburning practice according to their growth process. The stands over 15 years can be underburned at the frequency of 1-4 years/ time depending on the closure of the stand and the load of fine fuel under the crown. It is suggested that the factors involving the prescription be divided into two groups--the influential ones and the lifiting ones depending on their inportance to the underburning. The emphasis is laid on the unified effects of all factors on the underburning. A prescription of underburning of the two species suitable to the climate and geography of Yunnan, and proper method of operation and crew organization are given in this paper.

KEYWORDS: $P$. Yunnanes is and $P$. Kes is Var. Langbinensis, underburning

\section{INTRODUCT ION}

The Yunnan forest region, which is located in the Southwest part of China, is one of the four largest in this country. $P$, yunnanesis and $P$. kesiya var. langbianensis are special timber species in Yunnan province. These two species, extending approximately from a latitude $22^{\circ} 30^{\circ}$ to $29^{\circ}$ North and a longitude $98^{\circ} 30^{\circ}-106^{\circ}$ East, make up as much as 63.3 percent of the province's total forest area, and 42.6 percent of its total standing stock $[1]$.

Due to the unique geographic and climatic condition in the region, forest fires have been a major problen for forest protection in the province. Host fires occurred in the forest of the two kinds of pines mentioned above. For example, Statistical data, over a 5-year period, 1980 to 1984 in counties comprising. 61.3\% total forest area where the main distribution of these two species occur, shoved that there were 14,992 fires, which made up 77.8 percent of the province's total fires and 371,867 hectares were damaged, which is 68.3 percent of the total damaged forest in the province. 0bviously, getting fire occurrence in this part of the forest under control would have significant effects on the reduction of the province's forest fire. 
In order to change the passive suppression to active prevention, studies and demonstration on underburning have been made since the $1980^{\circ} \mathrm{s}$. Technique for underburning suitable to the stands has been developed and become an effective measure in fire prevention and stand management. For example, there were more than 120,000 hectares of the stands underburned in the province in 1990.

\section{MATER IAL AND METHOD}

Investigation on Stand Characteristics and the Fine Fuel Under the Crown (F.F.U.C.)

In investigation, the whole distribution area was divided into three subregions: (a) Southern, with an annual precipitation over $1000 \mathrm{~mm}$ and an annual temperature summation of $\geqslant 10^{\circ} \mathrm{C}$ over $6000^{\circ} \mathrm{C}$; (B) Northern, with annual precipitation less than $1000 \mathrm{~mm}$ and an annual temperature summation of $\geqslant 10^{\circ} \mathrm{C}$ less than $6000^{\circ} \mathrm{C}$ and (C) the dry valleys. 21 sites each of $20 \times 20$ meters in 7 counties among the 3 subregions were investigated and the age, height, D.B.H. and the under branch height (U.B.H.) for the stands were measured. 5 quadrants each $1 \times 1$ meter were sampled from each site to measure and record the litter loading, the species height and loading of weeds and brush less than $1 \mathrm{~cm}$ in diameter. To calculate the dry loading of the F.F.U.C., moisture content for each type of the fuels above was measured.

The Development of Underburning Prescription

The experiments were made in the forest areas of Gejiu City and the Nan Pang River Forestry Bureau, representing the Southern subregion; and in those of Yong Ren County, representing the dry valley subregion. Investigations were also made for burned areas in other counties. The burning conditions for both the unsuccessful underburning and forest fires during the emergency fire season were recorded. The factors which were measured are: fuel characteristics, meteorological elements, geographic factors, fire behavior and the effects of burning.

\section{Underburning Techniques And Crew Organization}

The several ignitions such as head fire, backing fire and flank fire and modes of burning operation have been tested to determine a better pattern of crew organization and dispatch as well as the equipment and tools to be used.

\section{RESULTS AND DISCUSSIONS}

The Effects of Stand's Age and the Characteristics of the F.F.U.C. on the Underburning

The effects of stand age on the underburning. Table 1 gives detailed information for 7 stands typical of the middle-aged forest and the young plantation. It is obvious that, due to the fact that the average height of 
the weeds and bushes is very close to that of the young trees, site 1 and 2 have very good vertical fuel continuity. Since needles and twigs are also fine fuels, the whole stand 111 be destroyed, if the underburning is to be conducted here. Therefore, underburning can not be practiced in this kind of plantation.

In site 3 and 4 , the vertical continuity of the fuel distribution has been broken. The average U.B.H. of the plantation has reached up to 3.5 meters, the average height of the fine fuel reaches about 1.0 meter. But, these are mean figures. There are still some weeds and bushes that reach the height of the young trees and interlocked with the branch of the lower crown. It seems that the underburning in this type of stand is likely to cause crown fire to some extent but with much smaller damage to the whole plantation, so it can be achieved if some measures are taken prior to underburning. Experience from rules of thumb shows that the underburning can be well accomplished if the stands are thinned before underburning. In this way, the crown fire can mostly be avoided when the underburning is operating in the stands. "Gaps of about 1.5 flame heights between crown bases and surface or middle fuels will virtually preclude the development of crown fires"[2]. In fact, the underburning in 10-15 year old stands may cause comparably high mortality (about 12\%), but about 95\% of those killed by fire were suppressed trees which would otherwise have been eliminated by natural thinning in the stand. Fortunately, the two species are light demanders and the process of natural thinning has an earlier start and with a greater intensity. In stands younger than 10 years, the density may be as high as 10,000 stems/ha. In stands over 10 years of age natural thinning occurs and the thinning increase as the stand grows older. In a stand between $10-30$ years, this reduction may reach as much as $80-85 \%$, and 50 years later, there is only $10 \%$ left[1]. This means that at least $85 \%$ of the trees in a 10 year old stand could be killed by fire. From this point of view, underburning can not only reduce the fire hazard but also achieve the thinning.

TABLE 1. Stand characteristics, height and loading of fine fuel under the crown of various age $P$. Yunnannesis and $P$. Kesiya var. langbianensis

sites age closure density
(yr.)

* mean U.B.H. = mean under branch height

**F.F.U.C. = fine fuel under the crown

For the stands over 15 years, no pretreatment of the fine fuel was needed. Since the stand had already undergone underburning several times, the loading of the fine fuel under the crown is auch lower while the U.B.H. 
has a greater increase and a crown fire is not likely to occur (table 1). Site 6 and 7 also show that as the stand gets older, the U.B.H. will increase and the fine fuels loading under the crown will decrease, therefore, the intervals of the burnings can be longer.

The effects of the fine fuels under the crown on the underburning. The species and quantity of the weeds and bushes as well as the quantity of fallings in the stands vary with the site conditions and the biological natures of the species. Generally speaking, in sites with a good supply of water and sunlight, trees will grow better, the weeds and bushes will also thrive, which in turn, increase the fine fuel loading. For instance, in the southern subregion, the mean height of the weeds and the bushes is $1.1 \mathrm{~m}$. and the mean loading of the fine fuel is $7.75 \mathrm{~T} / \mathrm{ha}$, those are $37.5 \%$ and $25.8 \%$ more than those in the Northern subregion which are only $0.8 \mathrm{~m}$. and $6.16 \mathrm{~T} / \mathrm{ha}$, respectively (table 2). In fact, the fine fuel loading under the crown accumulates over years. It is the difference between the production and decomposition in the same period of time. This explains why the fine fuel loading under the crown in the dry valley are higher than those in the other two subregions (table 2). In the dry valley, the plants all grow poorly, but the F.F.U.C. are heavy because of much less precipitation and a shorter period of rain, which is unfavorable to the activities of the microorganism resulting in little decomposition of the fallings.

TABLE 2. Height and loading of fine fuel under the crown of stands in various subregion

\begin{tabular}{|c|c|c|c|c|c|c|}
\hline Subregion & $\begin{array}{l}\mathrm{Nu} \text {. of } \\
\text { samp les }\end{array}$ & $\begin{array}{l}\text { range of } \\
\text { closure }\end{array}$ & $\begin{array}{l}\text { heigh } \\
\text { range }\end{array}$ & $\begin{array}{l}\text { (m) } \\
\text { mean }\end{array}$ & $\begin{array}{l}\text { loading } \\
\text { range }\end{array}$ & $\begin{array}{l}(\mathrm{T} / \mathrm{ha}) \\
\text { mean }\end{array}$ \\
\hline Northern & 8 & $0.4-0.8$ & $0.4-1.2$ & 0.8 & $2.5-13.7$ & 6.16 \\
\hline Southern & 10 & $0.4-0.9$ & $0.4-1.5$ & 1.1 & $2.9-11.8$ & 7.75 \\
\hline Dry Valley & 3 & $0.4-0.6$ & $0.2-1.0$ & 0.5 & $6.4-13.1$ & 10.31 \\
\hline
\end{tabular}

The result also shows that the fine fuels loading under the crown is negatively related to stand closure (table 3 ). This is obviously related to the sunlight reaching the ground. In the open forest of the closure $(0,4)$, there is larger light-demanding cover, making up a greater proportion in the fine fuel, while in the stand with a closure $>0.8$, there are only a few tolerant plants. Fine fuels are mainly made up of fallings. In terms of absolute loading, the loading of F.F.U.C. in the stand with closure $\leqslant 0.6$ is more than twice as much as that in the stand with a closure 0.6 (table 3 ).

TABLE 3. Loading of fine fuel under the crown in various closure stands

\begin{tabular}{lccccc} 
Closure & 0.4 & 0.5 & 0.6 & 0.7 & $>0.8$ \\
Number of samples & 6 & 2 & 4 & 5 & 4 \\
Range of loading (T/ha) & $3.4-14.4$ & $7.9-17.3$ & $6.5-11.8$ & $2.0-9.3$ & $2.5-4.9$ \\
Mean loading (T/ha) & 8.7 & 12.6 & 10.3 & 4.7 & 2.6 \\
\hline
\end{tabular}

These difference of the fine fuel under the crown in both stands of 
different closure and subregions are of great importance in selection of frequency, prescription and the techniques of underburning. A standard for underburning the two pine's stand is proposed in table 4. The bas is for the proposal, theoretically should be under branch height and fine fuel loading under the crown, but both are not easy to determine in the field, so the age and closure of the stand are used as subsidiary. Because of the difficulties in the reforestation and the management in the dry valleys, the ecological effects of the stands are of special significance. The lower intensity and higher frequency of burning must be maintained here so as to reduce the hazardous fuel under the crown on one hand without causing any erosion on the other.

TABLES 4. A recommended standard for underburning in stands of 10-30 years of age

\begin{tabular}{|c|c|c|c|c|c|}
\hline Subregions & $\begin{array}{c}\text { age } \\
\text { (years) }\end{array}$ & $\begin{array}{l}\text { mean } \\
\text { U.B.H. } \\
\text { (II) }\end{array}$ & closure & $\begin{array}{l}\text { burning } \\
\text { conditions }\end{array}$ & $\begin{array}{l}\text { frequency of } \\
\text { underburning } \\
\text { (years/time) }\end{array}$ \\
\hline Northern & $\begin{array}{l}12-20 \\
21-30 \\
12-20 \\
21-30\end{array}$ & $\begin{array}{l}3.5-6.0 \\
6.0-14.0 \\
3.5-6.0 \\
6.0-14.0\end{array}$ & $\begin{array}{l}\leqslant 0.6 \\
\leqslant 0.6 \\
0.6 \\
0.6\end{array}$ & $\begin{array}{l}\text { low } \\
\text { low-niddle } \\
\text { low-middle } \\
\text { middle-high }\end{array}$ & $\begin{array}{l}1-2 \\
2-3 \\
2-3 \\
3-4\end{array}$ \\
\hline Southern & $\begin{array}{r}9-20 \\
21-30 \\
9-20 \\
21-30\end{array}$ & $\begin{array}{l}3.5-7.0 \\
7.0-16.0 \\
3.5-7.0 \\
7.0-16.0\end{array}$ & $\begin{array}{l}\leqslant 0.6 \\
\leqslant 0.6 \\
0.6 \\
0.6\end{array}$ & $\begin{array}{c}\text { low-middle } \\
\text { middle-high } \\
\text { middle-high } \\
\text { high }\end{array}$ & $\begin{array}{l}1 \\
1-2 \\
1-2 \\
2-3\end{array}$ \\
\hline Dry valley & $\begin{array}{l}13-20 \\
21-30 \\
13-20 \\
21-30\end{array}$ & $\begin{array}{l}3.5-5.0 \\
5.0-12.0 \\
3.5-5.0 \\
5.0-12.0\end{array}$ & $\begin{array}{l}\leqslant 0.6 \\
\leqslant 0.6 \\
>0.6 \\
0.6\end{array}$ & $\begin{array}{c}\text { low } \\
\text { low-middle } \\
\text { low } \\
\text { low-middle }\end{array}$ & $\begin{array}{l}1 \\
1-2 \\
1-2 \\
2\end{array}$ \\
\hline
\end{tabular}

Prescription for the Underburning in the Pine Stands

Underburning can only be achieved under a combination of permissible environmental factors and the fuel characters (table 5-7). Some of them involving factors such as type and loading of fuel, slope and its aspects and temperature may be considered as influential factors since they can affect the behavior of the fire. While some other factors such as the moisture content of the fuel, speed and direction of the ind, relative humidity etc. may be called the limiting factors or key factors. The limiting factors have a much greater effect than that of influential factors on fire behavior. Two or even one, of the lititing factors may determine if the burning can be started or sustained or cause the fire to escape. This classification is helpful because people have a better understanding of the burning conditions and concentrate on the liniting factors instead of the influential ones. The limiting factors and the critical values used in the practical operation are outlined in the table 5. These volumes, of course, are not absolute. For example, if an adequate fire control crew is available, and fire breaks are also very effective, a stronger wind than what is listed in the table 5 would also be acceptable, 
merely with a high cost.

For a specific stand, the integral effects of the various factors in the prescription are of greater importance than any single one because those factors interact and have internal relationships. For example: on the South side of the hill, it has a drier soil and higher temperature, thus the moisture content of the fuels will accordingly be lower, while on the

TABLE 5. Limiting factors and their critical values for underburning

\begin{tabular}{|c|c|c|}
\hline factors & value & possible result \\
\hline $\begin{array}{l}\text { mo isture content } \\
\text { of dead fuel }(\%)\end{array}$ & $\begin{array}{l}\geqslant 30 \\
\leqslant 5-7\end{array}$ & $\begin{array}{l}\text { no ignition or sustain burning } \\
\text { burning too intensity }\end{array}$ \\
\hline $\begin{array}{l}\text { moisture content } \\
\text { of living fuel (a) }\end{array}$ & $\begin{array}{l}\text { herbs } \geqslant 100-120 \\
\text { woody } \geqslant 140-160\end{array}$ & $\begin{array}{l}\text { will not burn even after dead } \\
\text { fuel has burned out }\end{array}$ \\
\hline $\begin{array}{l}\text { vind velocity } \\
\text { (m/second) }\end{array}$ & $\geqslant 9-11$ & $\begin{array}{l}\text { easy to burn out of site or } \\
\text { suppression of the fire }\end{array}$ \\
\hline tive humidity & 90 & cannot ignite or sustain \\
\hline
\end{tabular}

TABLE 6. Some examples of underburning conditions, fire behavior and burning effect in the stands

\begin{tabular}{lrrrrr} 
site & 1 & 2 & 3 & 4 & 5 \\
slope (degree) & 15 & 25 & 35 & 40 & 20 \\
aspect of slope & $\mathrm{S}$ & $\mathrm{N}$ & $\mathrm{NE}$ & $\mathrm{NE}$ & $\mathrm{NW}$ \\
temperature ( $\mathrm{C}$ ) & 22.5 & 21.2 & 14.4 & 21.0 & 23.0 \\
Wind velocity (m/s) & 2.7 & 2.7 & 0.7 & 1.0 & 1.3 \\
relative humidity (\%) & 52 & 57 & 50 & 35 & 55 \\
dead fuel loading (T/ha) & 5.7 & 5.6 & 15.5 & 20.5 & \\
dead fuel moisture content (06) & 85.0 & 91.0 & 98.8 & 14.8 & \\
head fire flame depth (m) & 1.45 & 1.0 & 2.0 & 2.3 & 2.0 \\
head fire spread rate (m/min.) & 2.75 & 1.2 & 2.5 & 3.5 & 0.9 \\
removed rate of fuel (\%) & 93.3 & 84.6 & 90.9 & 96.9 & \\
"flower face" rate (0/6) & 10 & 30 & 10 & 5 & 15 \\
\hline
\end{tabular}

* "flower face rate" $=\frac{\text { unburned area }}{\text { total planed burning area }} \times 100 \%$

North side, the fuels will be different from those of the South side, and have a higher moisture content, leading to relatively lower burning conditions (table 6, site 1 and 2). As in site 4, it had a lower wind speed $(1.0 \mathrm{~m} / \mathrm{s})$ and higher living fuel moisture content $(98 \%)$ compared with those of site $1(2.7 \mathrm{~m} / \mathrm{s}$ and $85 \%$ respectively), which is unfavorable to burning. but it had a steeper slope $\left(40^{\circ}\right)$, a lower relative humidity (35\%) and a much greater fuel loading $(27.5 \mathrm{~T} / \mathrm{ha})$. All of these made both the burning condition and burning results better than those of site 1 (table 6). In short, an adequate fire prescription is essential for successful 
underburning. An underburning prescription suitable to stands of $P$. yunnanensis and $P$. keisiya ver. langbianensis is proposed in table 7 . Since all the factors concerned can not be on the ideal point at the same time, they ust be comprehensively considered. Generally, an underburning can be conducted if more than half of the factors are of middle to high point.

TABLE 7. A recommended prescription of the underburning in the stands

$\begin{array}{lcr}\text { date } & \text { Nov. } 20 \text { th-Jan.10th } & \text { Dec. Ist-Jan.31st } \\ \text { loading of fine fuel (T/ha) } & \geqslant 10 & 10 \\ \text { Slope (degree) } & \geqslant 35 & \langle 35 \\ \text { temperature ( } \mathrm{C}) & 5-25 & 0-20 \\ \text { relative humidity }(\%) & 75-40 & 60-35 \\ \text { moisture content of dead fine fuel (\%) } & 25-15 & 20-12 \\ \text { moisture content of living fine fuel (\%) } & 100-80 & 90-60 \\ \text { wind velocity (m/second) } & 1-4 & 1-6\end{array}$

Tining and Techniques of Underburning and Crew Organization

Timing of undrerburning. The time to achieve the greatest efficiency in underburning will preferably be from late November to early February in Yunnan where the year is alternatively divided by a dry and rainy season. This is because that during this time of the year, the annual herbs have already died and have a lower moisture content. The meteorological elements concerned are at moderate level; trees are in dormant stage, thus are highly fire resistant; the underburning is immediately followed by the critical fire season (February to April). As a rule, during the burning operation period, the stands of open forest, the stands deserving first burning and the pure conifer stands should be burnt first. Then the closed stands, the mixed stands, and the stands which were underburning previously. The stands on the steep slope and south side of a hill should be burned in the morning and the stands on the gentle slope and north side of a hill in the afternoon. In this way, the natural differences of the burning conditions in stands can be largely eliminated, getting a better burning result.

Burning techniques and crew organization. There are many burning techniques that have been developed by now because they are the managers greatest and sometimes sole control over fire behavior and smoke production. Readers who are interested in those can further refer to some related literatures ${ }^{[2]}$. The following recommended in this paper is used in Yunnan.

In Yunnan province, mountainous regions makes up $63.5 \%$ of the total area and highland $30.5 \%$ of the total area. It has a complicated topography with most of the mountains having a absolute altitude difference of 1500 2000 meters, and most of the slope being over 35 degrees, so the burning techniques must be in accordance ith those features.

Burning fire lanes: A fire lane up to 20-30 meters wide around the planted area should be cleared so as to ensure a safe operation. Roads and rivers are natural barriers to be preferably utilized, but there are still sections in some locations which need to be cleared before the underburning. $A$ and $B$ in figure 1 are illustrations of patterns for burning $f$ ire lane at different locations. When building a ridge fire lane, a control line of 


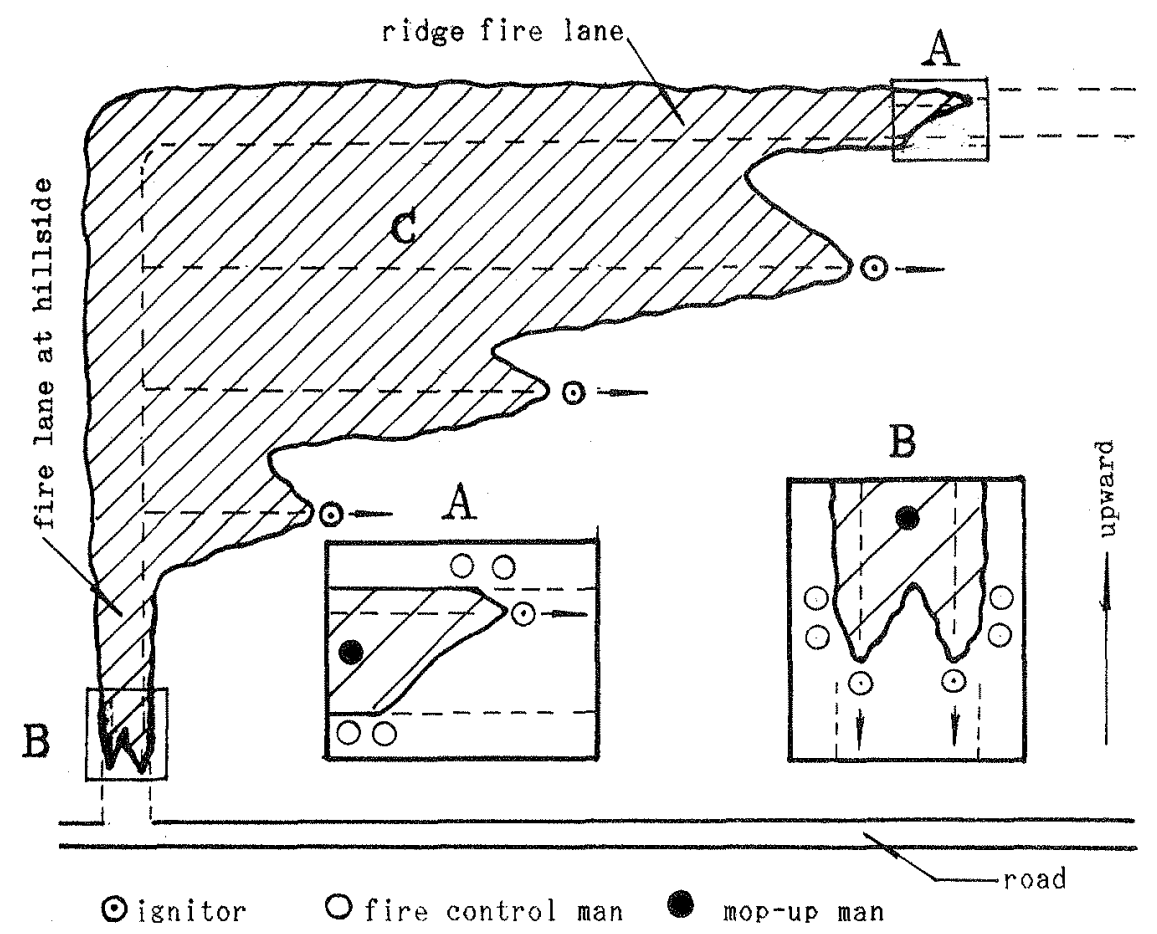

FIGURE 1. a diagram on patterns of operation of burning fire lane and underburning, A. burning of $r i d g e$ fire lane, B. burning lane at hillside and $\mathrm{C}$. underburning.

2-3 meters wide must be cleared at the upper part of the ridge. An igniter starts a fire along the ridge, a fire control crew puts out the upward fire on the upward side when the fireline spreads to a width of $2-3$ meters, leaving the downward side of the backing fire to burn enough (figure 1-A). When building fire lane at hillside, each of the two igniters opposite to each starts a flank fire along the predetermined line, then it is put out by the fire control crew after reaching a width of 2 meter (figure 1-B). Both of those patterrs of burning have a mop up man, who must be at least 20-30 meters behind the fire lane building group, to do the mop-up before going on.

Underburning: once all the fire lanes required are cleared, the prescribed burning can be carried out, using the upward fire as shown in figure 1-C. The igniter for the first strip must be at least 50-60 meters ahead of the igniter before the second strip igniter can start his work so as to insure safety, tc. The width of the strip is important. If the strips are too wide, the upward fires will have a longer way for acceleration, which is easy to cause crown fire; otherwise, the operation will be of low efficiency and poor results. Generally, the strips should be spaced at 20-40 meters apart depending on the slope and fuel loading.

In the whole course of the underburning, the commander who has the 
most important role should be in a position from which the whole operation area can be seen, and be able to communicate with every man by radio. The equipment and tools used are the No. 2 tool ( a mop-like hand tool made of wire) and a fan machine for fire suppression.

Literature cited

[1] Xue Jiru. Eorests in Yunnan, pp. 125-147. Yunnan Science and Technique press, 1986 (in chinese).

[2] Chandler, C., Cheney, P.,Thomas, P.,Trabaud, L. and Williams, D., Eire in Forestry, Vol. I, pp. 44, Vol. Il, pp. 224-229, John Wiley \& Sons, New York, 1983. 
